\title{
Standing in the Chaos: Cross-cultural Competency in Curriculum Materials
}

\author{
Tamara Gray*
}

\begin{abstract}
Many factors influence the success of an educational program. The curriculum, represented in the what, how, and who of instruction, is a critical component of such an achievement. When learning materials and teachers represent a "mainstream" point of view, the educational achievement of minority-identity students can be affected negatively (Horton \& Freire, 1990). For students of nonmajority communities (whether ethnic, linguistic, religious, tribal, or any other distinguishing identities), the cross-cultural competency of educators has become an important indicator of success for the educational institution that seeks to serve all of its students (Wolff \& Booth, 2017).
\end{abstract}

Keywords: Cross-cultural competency, curriculum, textbooks, tawhid, Nana Asma'u

\section{Muslim Students and Mainstream Curriculum}

Muslim students are especially vulnerable to a lack of cultural competency in educational institutions. Mainstream curriculum typically ignores indigenous knowledge (Prakash \& Estava, 2008) and worldviews (Au, 2012). Globally, when Muslim-majority countries import mainstream curricula from organizations and geographic locations where they are not the majority audience (and when private Muslim schools in Muslim-minority countries use the same), students are at risk of internalizing stereotypes and Islamophobia even as they learn in an inclusive environment. I have worked as a consultant to some of these institutions, and while Muslim nation-states may order books that are censored because of some content (political and sometimes moral), the materials still remain void of cultural competency in terms of their relationship to Muslim audiences.

\footnotetext{
* Tamara Gray is the founder of Rabata, an organization dedicated to promoting positive cultural change through creative educational experiences. She holds a doctorate in Leadership (University of St. Thomas), a master's degree in Curriculum Theory and Instruction (Temple University), and spent twenty years studying traditional and classical Islamic sciences, the Quran, and Arabic in Damascus, Syria. Currently, she is Rabata's Executive Director and Chief Spirituality Officer.
} 


\section{The "Trojan Horse" of Learning Materials}

Barend Viaardingerbroek (2015) has criticized education as a human right as a social engineering project disguised as a universal necessity. He does not deny the global need for learning, but rather likens the movement and the labeling of education as a "human right" to a Trojan Horse. In this vein, Prakash and Esteva (2008) point out that "This 'evolution' has transmogrified peoples and cultures so profoundly that previous virtues are now reduced to vices, and traditional vices have been elevated to virtues" (p. 22). This was indeed my assessment while serving as a consultant and editor of numerous curricular materials during the years 2008-2014.

In 2014, for example, the Ministry of Education of a Middle Eastern country required that their English-language books be edited for cultural sensitivity and competency. The Western-based publishing company complied by adding Arab and Muslim names and faces to the textbooks. The new exercises seemed to be diversified on the surface, because they now included Arab and Muslim men and women. Nevertheless, the text's exercises still contained orientalist and Islamophobic stereotypes and tropes. For example, when teaching about time, the students could choose answers to match the clock face, wherein answer "a" was a Muslim-Arab woman who slept until 1:00 pm, while answer "b" was a white European man who got up bright and early at 7:00 am - a clear example of embedding old orientalist and negative claims about non-Western people of color.

On another occasion, I was involved with an organization hired to help write the educational standards for an Arab-majority Muslim country. I was surprised to find that the person hired to set the standards for Arabic language learning did not speak a single word of Arabic. Upon inquiry, I was told that speaking Arabic was not important and that her experience in setting standards for English was sufficient. To assert that linguistic variance makes absolutely no difference in educational standard setting is a very shocking claim of cultural superiority. The project went forward, and nothing of nuance regarding the Arabic language was written into the nationwide learning standards.

Muslim students are taught what others think of them under the guise of normalized curriculum materials and are almost never exposed to what they think of themselves. They are told that they are oppressed, that sexism is rampant, and that terrorism and violence are natural to their very selves. Under these circumstances, they are at risk of poor academic achievement and internalized Islamophobia ( $\mathrm{Au}, 2012)$. In Minneapolis public schools, for example, the novel The Breadwinner (Ellis, 2010/2015) is commonly taught at the middle school level. The back cover touts it as "... a graphic geopolitical brief that's also a girl-power parable," but the girl power is rooted in Western and White understandings of power. In order to contribute to the family, she must dress as a boy and become the "breadwinner."

The book specifically describes traditional female Afghani dress (the burqa) as inconvenient and uncomfortable. She asks her father, "How do women in 
burqas manage to walk along the streets?" to which her father replies, "They fall down a lot" (Ellis, 2010/2015, p. 23). Similar messages are found in English literature canon books such as Frankenstein (Imady, 2015), Jane Eyre, and Anne of Green Gables. The Trojan Horse of education has pulled Muslim students around the world inside of it and taught them about themselves from the perspective of the colonialist peoples who had been their oppressors.

The question of cultural relevance in curriculum thus becomes a crisis of identity, one that Muslim educators are uniquely qualified to address.

\section{The Muslim Foundations of Cultural Competency}

Muslim attitudes toward an "other" were addressed in the first days of the developing Muslim society. Revelation occurred in a highly individualistic society made up of warring tribes, nomadic cultures, some agricultural areas, and a trading culture that brought in goods from surrounding lands and peoples. When the long years of war subsided and Madina became the center of the new Islamic leadership, numerous tribes and peoples came to learn about the new religion that the Quraysh had embraced (al-Zayid, 2018, vol. 1).

In the early days, while the Prophet (s) was still in Makka, he is recorded to have interacted with many diverse peoples. Makka was visited by tribes from all over the Arabian Peninsula, and the Prophet interacted with all of them for educational purposes. Sensitive to each one's cultural context, he performed miracles for the Bani Amir b. Sa'sa'a, who were known to dabble in sorcery (al-Zayid, 2018, p. 271); understood political ties with the Bani Shayban, who had an agreement with Persia (p. 272); and sought out the Banī Muharib's eldest man, who was 120 years old according to early sources (p. 272). In each of these stories, we see the Prophet make a conscious effort to understand the peoples he was approaching for dialogue and teaching. We see no erasure of their cultural context, but rather an awareness of it and the ability to interact with it.

Later, when war abated in the ninth year after hijra, the Prophet (s) met people of many different backgrounds and cultural needs. He taught them and demonstrated cultural competence even though, by this point, he was in the position of the cultural majority and the dominating political power. When the Bani Tamīm arrived in Madina, they offended the Companions by shouting to the Prophet (s), "Come out to us, Muhammad!" (al-Zayid, 2018, vol. 2, p. 338) and then held him (s) back from the prayer to speak about their issues. The Prophet teaches us about cultural competence - his response is neither denigrating nor cold, but rather engaging and accepting. After praying, he sat in the masjid and the tribe's poet spoke. The Prophet then called his poets to respond, and both groups engaged in a poetry competition. This method - a poetry slam in modern terms - was useful in this case because this tribe valued poets, poetry, and the skill of reciting it. 
For the people of Murra, however, the Prophet did not engage in a rhetorical showdown. Instead, he inquired about their land, the persistent drought, and their needs. He then prayed for them, gave them gifts of money, and showed them compassion - all while teaching them what they had come to learn (pp. 403, 404).

The Hamdān, a tribe hailing from Yemen, received a letter from Prophet Muhammad (s). A people of appearance, they wore their fancy tailored and embroidered clothes while visiting him. And he complimented them on their goodness, saying, "How wonderful are the people of Hamdan, how quickly do they achieve victory, and how patient they are with hard work, and from them are the pillars of Islam" (pp. 405, 406).

If cultural competency is the ability to understand, communicate with, and effectively interact with people across cultures, then we see this clearly in the above examples. But was this part of his personality or part of the religion he taught?

Tawhìd and Cultural Competence

The foundational attitude of inclusion is found in the theological roots of tawhīd. In her Wholeness and Holiness in Education: An Islamic Perspective, Zahra al Zeena (2001) describes applying this Islamic concept to teaching and learning in the following terms, "The Islamic paradigm as a holistic, integrated paradigm is divine, spiritual, religious, eternal, constant, absolute and ideal. On the other hand, it is human, material, rational, temporary, mutable, and relative. These two opposites are intimately interwoven by tawhìd" (p. xxvii). She calls this the "dialectics of tawhìd" and shows throughout her book how it can be applied to knowledge production and teaching/learning.

We see the Prophet's practice in terms of understanding, communicating, and interacting with others as a demonstration of this tawhìd because he (s) interacts with the messy human realities of those he meets from his (s) place of spiritual and religious grounding. He sees them clearly and reaches them at their own level, but with a tawhìd $\bar{\imath}$ understanding and approach that opens the door for education. Cultural competence, when pursued under the banner of tawhìd, can interact with the secular and the sacred as well as bring gentleness and respect to that interaction.

Introducing this concept into teaching and learning - and the cultural competency necessary for both activities - implies reducing fragmentation and including the sacred and the secular. Curriculum materials that normalize xenophobia should not exist in a tawhīd-based system.

\section{Dissipative Structures, Complexity Theory, and Solving the Problem of Cultural Incompetence}

Ilya Prigogine won a Nobel Prize in 1977 for his description of dissipative structures. In simple terms, he discovered that there were physical and chemical 
systems far removed from equilibrium but nonetheless apparently demonstrated order within what was originally defined as chaos and seemed to be selforganizing (Capra, 2002). This was a breakthrough in modern science, because it seemed to flatten space and time.

In the realm of social thinking, dissipative structures, including education, help us understand seeming chaos as a self-organizing problem (Capra, 2002). For example, as stakeholders criticize modern educational systems regarding cultural competency, one may ask if these systems, developed to raise a citizenry for the industrial era, can address the educational needs of today.

According to chaos theory, transformation will only occur insofar as the original "DNA," or project structure, remains intact. Hence, the question of cultural competency becomes critical. As stakeholders add energy to the structure, which in this case is a mainstream educational system, the system will begin to transform itself to accommodate that transformation, whether the stakeholders are prepared or not. If dialectic tawhìd were to contribute to cultural competency in education, the energy applied to the dissipative structure (the educational system) would form itself into a more culturally competent structure. In fact, the systems would begin to undergo exactly the same process regardless of the stakeholders' readiness or lack thereof (Capra, 2002).

Chaos (or complexity) theory includes autopoiesis, the understanding that living systems can create and renew themselves and that this process is both the norm and the catalyst for diversity and uniqueness (Capra, 2002). Further, instead of seeing life as represented in one single cell, it sees life as a network of connected pieces. In other words, we understand it as an interwoven whole -tawhìd, or the unity of living things. Unity, as readily demonstrated by connected things and autopoiesis of biological matter, helps us understand the connectedness of all the pieces of social life, and especially as manifested in educational systems. The concept of a dissipative structure moves our focus away from a quest for stability and forces us to see that open systems maintain themselves with energy and change. Instability is not something "foreign," but rather the natural norm of existence (Capra, 2002).

This thinking is in line with Al Zeera's definition of dialectical tawhìd and contributes much to the idea of cultural competence in education. Recognizing education as a dissipative structure comprising autopoietic factors enables us to embrace change rooted in tradition (as biological change remains rooted in DNA) and to uplift those values of the communities that are part and parcel of the education that is no longer happening to them, but rather with them.

\section{The Curricular Standpoint Theory}

Building on the dialectics of tawhìd, especially as described while using complexity theory, curricular standpoint theory reminds us to recognize the world- 
view of the student audience. So, while we expect transformation, we recognize that change must come from a familiar point.

Curricular standpoint theory points out that "...the issues of peoples and communities that are either regularly pushed to the margins of school knowledge, actively misconstrued within the curriculum or left out of the curriculum completely" (Au, 2012, p. 67) are important for learning. As such, Muslim students and other non-majority identities face greater challenges than mainstream populations do when interacting with their curricular materials. This theory helps us focus on what and how Muslim students are learning. The materials from which they are learning must not erase, misstate, or belittle Muslim culture and ontology. "Because being and knowing are dynamically intertwined within the dialectical relationship between consciousness and our environment...the content of the curriculum should relate to students' contexts, experiences, identities and material realities if it is to be effective" (Au, 2012, p. 67).

\section{Nana Asma'u's Pedagogy as an Example of both Tawhïd and Standpoint Theory}

Twelve hundred years after the Prophet's death and Islam had spread with his (s) example of openness and inclusion in teaching, the West African female scholar Nana Asma'u (1793-1864) developed a system of education that was inclusive of linguistic, geographic, and ethnic differences. Her self-designed intricate system of education, which addressed students of varying linguistic and ethnic backgrounds, featured a large teaching staff that she trained, as well as her own written curriculum. She was responsible for educating women over a thousand-mile region (Mack \& Boyd, 2000).

Concerning herself with their religious knowledge, language, leadership skills, and character, she wrote, "The women students and their children are wellknown for their good works" (Boyd \& Mack, 1997, p. 105). We see in her work evidence that social structures will self-organize along the lines of the energy applied to their transformation, the dialectic of tawhild, and the positive effects of a curriculum that "sees" who it is teaching (standpoint theory). Her work remains an excellent example of how we might create a method of inclusion and cultural competence for students across the globe today.

\section{Who was Nana Asma'u?}

Nana Asma'u's life was sandwiched between the French Revolution, which concluded in the year of her birth, and the American Civil War, which ended the year of her death. She lived during the Sokoto Caliphate, which spanned the area near Lake Chad in the east and Middle Niger in the west. Sokoto succumbed to colonial rule only in 1903 . 
Asma'u was born in 1793, married in 1807, and had her first child in 1813. She wrote her first known long work of prose poetry six years later. In 1817 she lost her father, Usman dan Fodio, whom she admired and held up as a spiritual example for others for the rest of her life. Her father was lovingly called Shehu, a rendition of the Arabic term "Sheikh," in reference to his great scholarship and spiritual acumen. Her beloved brother and colleague died in 1837, and her husband, who was her confidant and dear friend, passed away in 1849 (Boyd, 1989).

The Shehu ensured that both his daughters and sons were educated. All of them attended classes in the mornings and late afternoons. They learned to read and memorized the Quran's verses in between household chores and worship. Asma'u and her twin brother Hassan were the Shehu's twenty-second and twentythird children, and yet they were raised with gentle fatherly attention and advice (Boyd, 1989). It is said that Asma'u inherited her father's karāma, or personal miraculous blessings.

By the time she was married at fifteen, she had already garnered her spiritual respect to such a degree that her father came to her when his general (Bello, her older brother and later inheritor of the caliphate) was locked in a battle. He said to his daughter, "You see how Bello is struggling at Alkalawa" (Boyd, 1989). at which Asma'u took up a burning branch and, pointing it in the direction of the battle, said, "Burn Alkalawa" (Boyd, 1989). She was later told that Bello had won the battle because the battlefield had burned. This story became part of Sokoto's oral history and contributed to Asma'u's honor among them.

\section{Source material}

Nana Asma'u was unknown outside of Africa for over a century. But in 1984, after years of research into her life, Jean Boyd and Beverly Mack organized, translated, and published all of her known works. At that time computers were cumbersome and software clunky, so they experienced great difficulty organizing the works in their various languages and the English translations (Mack, 1998). It is, therefore, rather difficult to wade through.

They numbered the translations of each piece, but not the originals. The original writings are separated by language, and the African languages have been taken out of their original Arabic script and put into Latin script because that is how they are written today. The Arabic works are placed on pages left to right, making it difficult to remember which way to turn the page. This is especially confusing because the pages are not numbered. Each Arabic page is a photograph of the original, however, and as such includes a traditional clue at the bottom indicating the word that begins the next page. At least one page is misplaced, however, and that adds to the confusion. It is, nonetheless, an amazing collection.

The body of work had been stored in a goatskin bag in the home of Waziri Junaidu, one of Nana Asma'u's descendants. The poems were dated, which helped 
her biographers piece together the events of her life. Boyd extended her research beyond the manuscripts by traveling to villages to meet and talk with elderly female descendants of Nana Asma'u's students and teachers. Other books followed, all of which attempted to write her biography and the story of her transformative effect on her society. Here, I use Boyd and Mack's original research and their translations of Asma'u's work to showcase her ability to create culturally relevant curriculum materials and train culturally relevant and competent instructors.

\section{Curriculum}

The curriculum was a series of educational poems composed in the learners' spoken language. These poems were meant to teach the beginner basic religious knowledge, give the intermediate learner more advanced knowledge, and prepare the advanced learner to move on to more advanced learning using the poems as her base.

Nana Asma'u wrote these poems with an eye to her target audience's oral culture. They would be memorized before they would be read and read before they would be written, as the students progressed (Mack \& Boyd, 2000). One example of this curriculum is her poem "The Quran," a thirty-verse poem that teaches the name of each of the Quran's 114 chapters as well as their order. This beginning primer was the first step to the ultimate goal of memorizing the entire book. The following is a short excerpt:

I pray to God the Glorious

Through the honor, al-Hamdu and the Sura Baqara

And Aali Imrana and Nisa'u and Ma'idatu

Al-An'ami, al-'Arafi and al-Anfali and Bara' (Boyd \& Mack, 1997, pp. 38-43). ${ }^{1}$

The poem continues, weaving the chapters' names into sentences, thereby facilitating their memorization. This is an interesting and culturally relevant method of language and content instruction. The poem itself is written in Fuflfide but contains many Arabic terms - given the content - which enables the student to approach language learning from the comfort of familiar phrases and vocabulary.

In another poem, Asma'u teaches the entire sīra, the Prophet's (s) biography, in 316 two-line stanzas. Written in Fulfide, it taught both his life and contemporaneous political issues, such as her own role as well as the Sokoto Caliphate's importance, and encouraged national loyalty. It begins with an emotional love song spoken to God about Muhammad, after which the voice changes and

${ }^{1}$ Spelling changed from the transliteration of Mack and Boyd to reflect more accurate Arabic phonetic sounds. 
the poet begins speaking to her learners about history. Finally, at the end, Nana Asma'u ties the long history lesson to modern people and issues. She begins the poem:

We thank God for the radiance of the Prophet

The foremost of all creation, Ahmada. (p. 309)

O God, receive my song, may it please

You, and be acceptable to Muhammada

The constant repetition of Muhammada constitutes no flaw

Because this song is about repeating the name Muhammada. (p. 310)

Then in the next section she says:

Hasten countrymen and hear about

The noble character and place of honour (sic) of Muhammada

You will find out about his companions and hear about

The deed they performed during the time of Muhammada. (p. 310)

At the very end she concludes - after more than 300 verses:

I ally myself to him as my father did

And Sheikh AbdulQadir, Ahmada

And Shaikh Dasuqi, through them may I see the face of Muhammada

It is their help we seek in this world and the grave

And also in the Next World, so that we may see Ahmada. (p. 345)

The poem continues, but the point has been made. Nana Asma'u summarized 63 years of history - including battles, births, conversions, and family details - into a 316-stanza poem that respected and included the learning audience.

In another more theologically focused poem, she addressed death and the afterlife. Recognizing her students' animist origins, she spoke directly to their needs and described hell as worse than hornets, blackflies, and other local pests.

The components of the Fire are themselves fiery, worse than the blackness,

Worse than hornets or blackfly, they are huge and bite

And there are others like the tsetse fly and gnats and earth fleas whose bite is painful

Plus, black ants and red termites which have a fierce bite. (p. 357)

Her imagery is taken directly from her students' lives, for these insects are not mentioned in metaphors of hellfire directed at Arab desert dwellers. By using them as a metaphor for the "bite" of the fire, she is acknowledging and using her students" real-life experiences in the content and presentation of her teaching material.

All of the above poems, or "textbooks" as they were used by Nana Asma'u and her appointed teachers, demonstrate dialectic tawhīd as described by Al 
Zeera and curriculum standpoint theory. They worked as energy applied to thousands of women, and the resulting reorganization of their educational lives could still be seen in the late twentieth century (Harvard Divinity School). The sir $a$ poem, which teaches history and spiritual love for the Prophet (s), is both material and spiritual, addresses the students' needs, and includes important modern issues relevant to their lived lives. The poem about death and the afterlife is especially indicative of standpoint theory, in terms of its vocabulary (the mention of local pests), imagery (remembering her audience's animist origins), and culture - and in the very fact that it is an oral textbook. However, it is also dialectically tawhìd $\overline{\text {. }}$

Nana Asma'u demonstrated the push and pull of this life and the next, including religious teaching along with day-to-day instruction, by saying,

Your grievous sins have all been recorded, and even the less important ones

Everything you have done is remembered, even what you have said Everything about you will be seen by you in the grave.

You will meet up with everything you did in the past. It is accumulated and awaits you.

(Boyd \& Mack, 1997, p. 348).

This is straightforward teaching about death and the afterlife. But in the same poem, she also says,

He brings people into the world, gives them wealth,

Makes them prosperous and content, makes them used to it,

He makes them happy for a time, then he uproots them.

They are taken from the place they know

To a place they know not, very distant, whether they wish to go or not. (p. 347)

While this could be construed to imply heaven and hell, it is more likely a reference to the historical exodus forced upon the Sokoto Caliphate's people and possibly a reference to the thousands of converts whose lives had changed drastically during the same period. In other words, she was able to include the tension between real and tangible modern life and the less tangible (but no less real) teachings about the afterlife. The push and pull of dialectic tawhìd is obvious, the standpoint and personal trials of her students are appreciated, and the very writing of the curriculum is the energy needed to bring order to the chaos that was the lack of religious education among her students.

\section{Teachers}

Curriculum does not teach itself, and Nana Asma'u demonstrates her natural skill at cultural competency in her choosing and preparation of teachers.

Each team of personally recruited teachers included one advanced learner past the years of child rearing (over 40) and one advanced learner still in her pre- 
marriage age (under 14). Together they would sit with Nana Asma'u, learn the curriculum for that season, and then trek to their assigned village, where they would stay and teach the women. Sometimes they would return to Nana Asma'u with questions and thorny problems, and sometimes they would bring a woman with her own questions (Mack \& Boyd, 2000).

Before the tribes' mass conversion, visiting medicine women had garnered the villagers' respect with their spells and animist practices. These women wore large hats to signal their status. Asma'u, taking note of this, crowned her teachers with their own hat, one wrapped with a red cloth in a ceremonious manner (Mack $\&$ Boyd). She upheld the tradition of dress, acknowledging a cultural norm while adapting it to fit the teachers she was sending to the villages. She also created lists of prayers and verses that could be recited as ruqya, spiritual dispelling of disease and evil via exorcism, to both acknowledge and fulfill this local need.

When Jean Boyd went into rural Africa in 1981, she met Hauwa, a descendant of one teacher, who vividly described the days of the jan-taro (Nana Asma'u's teaching system) and her own role as a jaji (leader). She could recite every student of Nana Asma'u, including her first, thereby signifying the impact of these teachers on their students (Boyd, 1989).

\section{Counteracting Cultural Incompetency}

How can we reach into our history and bring forth concrete models or paradigms rooted in tawhi $\bar{d}$ and standpoint theory to counteract the lack of cultural competency in educational systems around the world?

Anyon (2014) calls upon educators to "Turn anger and despair into a commitment to struggle for justice" (p. 173). Her recommendations, set atop a foundation of dialectical tawhìd and curriculum standpoint theory and combined with the Prophet's example and Nana Asma'u's practical example, can be laid out in very practical steps, as presented below.

1. Help students appreciate their own value, intelligence, and potential: Curriculum needs to be analyzed for messages of subjugation and stereotypes and redone so that every learner can believe in "their own value, intelligence and potential as political factors" (p. 172). Nana Asma'u deeply respected her students and wrote beautiful poems about them that made their lives public knowledge. Her clear descriptions of these women's value, intelligence, and virtue bolstered succeeding generations and encouraged them to fulfill their own potential.

Today's Muslim students need to feel appreciated in the pages of the textbooks and literature that they are studying. It is not enough to just remove negative stereotypes; rather, they must be replaced with real-life examples that remind students of their own personal value.

2. Push back against the "stereotype threat" (p. 172): As we work to create culturally relevant and competent curriculum materials and think of ways to train in- 
structors, we should be aware that Muslim stakeholders may not fully engage because of previously learned stereotypes about themselves. Anyon points out that stereotyped instruction not only predicts failure as a self-fulfilling prophecy, but can also "mitigate against a perceived need to change the system" (p. 172).

Nana Asma'u's model of pairs of women sets a model of teamwork and partnership across generations and cultures from which today's Muslim can learn. The role that Muslim educators, chaplains, and leaders can play in curriculum development is only limited by our own willingness to engage creatively and contribute generously to the work of curriculum development and teacher training.

3. Create a counter-narrative: We need to provide literature with positive representations of normative Muslim characters and create learning materials that represent Muslims from the standpoint of Muslims (as opposed to the standpoint of mainstream curriculum authors). Educators need to help our students write a new story about themselves. Muslim students need to be engaged in relearning about themselves from themselves and rejecting the learning that comes from the dominant culture about Muslims.

This new story, one of empowerment and strength, then creates a feeling of positive entitlement. A counter-narrative is the energy required to do the work of dialectic tawhìd. The push and pull of narrative allow the dissipative structure of education to reform itself for inclusion, and Muslims can be both the recipients of cultural competency and the instigators of such cross-cultural competency for other communities.

4. Urge a stance of entitlement (p. 172): Muslim stakeholders need to develop a sense of entitlement. We have a right to live without Islamophobia, within and outside our own communities, and without sexism, racism, and xenophobia. This feeling energizes the available curriculum and causes a dissipative fissure that bursts into new and exciting opportunities for learning.

The term "entitlement" is not generally a positive term, but Anyon uses it to indicate the human right to respect. Curriculum standpoint theory forces others to respect the recipients of instructional materials because it attempts to stand together in the space of their viewpoint before creating the materials in the first place. Tawhīd embraces those viewpoints as part of the secular human world that stands as an important part of the sacred-secular interaction of teaching and learning. The sense of entitlement to learn and be educated, while allowing for cultural competency and respect, allows stakeholders to see the Trojan Horse of globalized "mainstream" curriculum and begin to create options and alternatives that include themselves in the who, what, and how of education.

\section{Conclusions}

The earliest days of Muslim teaching and learning were rooted in inclusion and culturally competent interactions. Dialectic tawhīd, as described by complexi- 
ty theory and standpoint curriculum theory, come together to help us identify historical practices that can counteract the lack of cultural competence in curriculum today. Using Anyon's steps to change, and considering Nana Asma'u's creative measures, it is time to both revamp Islamic studies material and to contribute to mainstream classrooms. We need to ensure that the fractal, or new pattern, caused by the energy thrust into the learning environment is one rooted in tawhìd and inclusion, as opposed to one that continues to "otherize" our very selves.

\section{References}

Al-Zayid, S. (2018). A compendium of the sources on the prophetic narrative, Vol. II. S. Imady, T. Gray, \& R. Mardini (Trans.), Minnesota: Daybreak Press.

Al Zeena, Z. (2001). Wholeness and holiness in education: An Islamic perspective. Herndon, VA: The International Institute of Islamic Thought.

Anyon, J. (2014). Radical possibilities: Public policy, urban education, and a new social movement. New York: Routledge.

$\mathrm{Au}, \mathrm{W}$. (2012). Critical curriculum studies: Education, consciousness, and the politics of knowing. New York and London: Routledge.

Boyd, J. (1989). The caliph's sister: Nana Asma'u 1793-1865 teacher, poet, and Islamic leader. New York: Frank Cass Publishers.

Boyd, J., \& Mack, B. (2013). Educating Muslim women: The West African legacy of Nana Asma'u, 1793-1864. United Kingdom: Interface and Kube Publishing.

Boyd, J., \& Mack, B. (1997). Collected Works of Nana Asma'u, Daughter of Usman 'dan Fodiyo (1793-1864). East Lansing: Michigan University Press.

Capra, F. (2002). The hidden connections: A science of sustainable living. New York: Anchor Books.

Ellis, D. (2015). The breadwinner. Toronto: Groundword Books.

Harvard Divinity School. Muslim women's religious literacy: The legacy of Nana Asma'u in the twenty-first century and beyond. Panel discussion May 2, 2014, from https://www.youtube.com/watch?v=DQrscNTDRQA\&t=3944s

Horton, M., \& Freire, P. (1990). We Make the road by walking: Conversations on education and social change. B. Bell, J. Gaventa, \& J. Peters (Eds.). Philadelphia: Temple University Press.

Imady, N. (2015). Burqa wearing belly dancers: Orientalist feminism in the formation of Middle Eastern and North African women identities. Unpublished undergraduate honor's thesis, St. Catherine's University, St. Paul, MN.

Mack, B. (1998). "This will not be handled by the press": Problems-and their solution-in preparing camera-ready copy for The Collected Works of Nana Asma'u, 1793-1964. History in Africa, 25, 161-169. 
Mack, B., \& Boyd, J. (2000). One woman's jihad: Nana Asma'u, scholar and scribe. Bloomington, IN: Indiana University Press.

Pasque, P. A., \& Nicholson, S. (2011) Empowering women in higher education and student affairs. Sterling, VA: Stylus Inc.

Prakash, M. S., \& Esteva, G. (2008). Escaping education: Living as learning within grassroots cultures. New York. Peter Lang.

Vlaardingerbroek, B. (2015). The global human rights education project: A "trojan horse" in Mercatornet, from https://www.mercatornet.com/articles/ view/the-global-human-rights-education-project-a-trojan-horse/16736 